\title{
Muhasebe ve Finansman Dergisi'nde Yayınlanan Makalelerin Bibliyometrik Analizi
}

\author{
Mustafa HOTAMIŞLI* \\ Iş11 EREM ${ }^{* *}$
}

\section{ÖZET}

Bu çalışma ile Ocak, Nisan, Temmuz ve Ekim aylarında olmak üzere yılda dört defa yayınlanmakta olan Muhasebe ve Finansman Dergisi'nde 2005-2013 yılları arasında basılmış makalelerin bibliyometrik özellikleri kapsamında incelenmesi amaçlanmıștır. Çalışmada nitel araştırma yöntemlerinden bibliyometrik atıf analizi tekniği kullanılmıştır. Bibliyometrik özellikler çerçevesinde değerlendirmeye alınan toplamda 562 makalenin analize tabi tutulduğu çalışmanın neticesinde finansal performans, kamu ekonomisi ve finansal piyasalar konularına ağırlık verildiği görülmüşürr. En fazla yayın yapan kurumlar arasında Marmara, Trakya ve İstanbul Üniversiteleri yer alırken, toplamda 112 kurum katkıda bulunmuş̧ur. Atıf yapılan kaynaklara bakıldiğında; ilk sirada dergiler, ikinci sırada diğer kaynaklar, üçüncü sırada kitaplar ve son sırada ise bildirilerin yer aldığ sonucuna varllmıştır. Muhasebe ve Finans Dergisi'ne toplamda 250 atı yapılmış, öz atıf sayılarının ise 224 olduğu görülmüştür. Çok yazarlılık durumlarına bakıldığında ise genellikle bireysel çalışmalara yer verildiği sonucu elde edilmiştir.

Anahtar Kelimeler: Muhasebe ve Finansman Dergisi, Bibliyometrik Analiz.

JEL Sinıflandirması: M41, F65, I21. \section{Finance}

ABSTRACT

This study evaluates the Journal of Accounting and Finance published four times a year in terms of the bibliometric characteristics and for this purpose, 562 articles published in the so-called journal between the years 2005-2013 have been analyzed. In the study, bibliometric citation analysis technique one of the qualitative research methods has been used. As a result of the study; it has been seen that financial performance, public finance and financial markets are the most common subjects of the articles. Marmara, Trakya and Istanbul Universities are the institutions having most articles and totally 112 institutions make contribution to the so-called journal. As for the references; the results have shown that journals are the first, other sources are the second, books are the third and notices are the fourth. There have been 250 citations to the Journal of Accounting and Finance and that co-citations are 224. When examining the author situation; it has been seen that there are commonly individual studies among the articles.

Keywords: The Journal of Accounting and Finance, Bibliometric Analysis.

Jel Classification: M41, F65, I21.

\footnotetext{
* Doç. Dr. Mustafa Hotamışı, Afyon Kocatepe Üniversitesi, İktisadi ve İdari Bilimler Fakültesi, hotamisli@aku.edu.tr

** Arş. Gör. Işı1 Erem, Uşak Üniversitesi, İktisadi ve İdari Bilimler Fakültesi, isil.erem@usak.edu.tr
} 


\section{GíRiş}

Herhangi bir bilim dalında gerçekleştirilmiş olan yazılı çalışmaların belirli dönemler itibariyle incelenmesi hem ele alınan bilim dalındaki gelişim düzeyinin belirlenmesi hem de ağırlıklı olarak hangi konular üzerinde yoğunluk olduğunun belirlenmesi açısından büyük önem arz etmektedir (Kozak, 2000: 16). Bilimsel dergilerin niteliklerini belirlemek amaciyla çok sayıda teknik geliştirilmiş olmakla birlikte, bu tekniklerden en sık kullanılanı bibliyometrik analiz teknikleridir. Akademik dergilerin niteliğinin belirlenmesi ve akademik yükseltmelerde dikkate alınması noktasında; tüm dünya genelinde ve Türkiye'de SCI, SSCI gibi önde gelen bir takım indekslerde yer alıp almamasına bağlı olarak bir takım değerlendirmelerde bulunmak mümkün hale gelmiştir. Ayrıca Ulakbim bünyesinde oluşturulan bazı veri tabanları sözü edilen konulara katkıda bulunmaktadır (Kozak, 2003: 148-152). Muhasebe ve Finansman Dergisi de 1998 yllindan bu yana yayınlanan ve alandaki gelişmeleri yakından takip etmeye imkân tanıyan akademik bir dergidir. Tübitak-Ulakbim, Ebscohost, Asos Index ve Index Copernicus tarafindan taranan dergi bünyesinde muhasebe ve finans alanında yapılan çeşitli çalışmalara yer verilmektedir.

Birçok farklı alanda yapılan çalışmaların hangilerinin daha kaliteli veya değerli olduğuna ilişkin olarak çeşitli değerlendirmeler yapılmaktadır. Yayın yapmanın yanı sıra bilim insanlarına ve bilimsel yayınlara ilişkin çok sayıda gösterge göz önüne alınmaya başlanması ile bibliyometrik analizler önem kazanmaya başlamıştır (Al, 2008: 264).

Çalışmanın amacı; Muhasebe ve Finansman Dergisi'nde yer alan yayınların bibliyometrik özelliklerini incelemektir. Nitel araştırma yöntemlerinden bibliyometrik analiz tekniği kapsamında ele alınan temel kriterler; makale sayısı, yazar sayısı, yazar profili, yazarların akademik unvanı, yazarların çalıştıkları kurum, makalelerin konusu, makalelerde kullanılan araştırma yaklaşımı, makalelerin sayfa sayısı ve anahtar kelime sayısı, makalelerde kullanılan yerli ve yabancı kaynak kullanımı, makalelerin kaynakçasında kullanılan kitap, dergi, bildiri ve diğer kaynak sayısı, özatıf ve dergiye yapılan atıf sayıları şeklindedir.

Çalışmanın ilk bölümünde; Türkiye'de çeşitli disiplinlere yönelik gerçekleştirilen ve yöntem olarak bibliyometrik analizlerden yararlanıldığ 1 çalışmalara yer verilmiştir. Daha sonra bibliyometrik analiz tekniği hakkında bilgi verilmiş, elde edilen bulgular tablo ve grafikler halinde sunulmuş ve ulaşılan sonuçlara ilişskin değerlendirmeler ve önerilerde bulunulmuştur.

Ele alınan derginin bibliyometrik açıdan ilk kez analiz edilmesi yapılan çalışmanın özgünlüğünü yansıtmaktadır. Diğer taraftan literatürde ilgili çalışmaların yönünü ve eğilimlerini göstermesi açısından da çalışmanın ilgili literatüre katk1 sağladığı düşünülmektedir. Ayrıca çalışmanın, bu alanda araştırma yapmayı düşünen araştırmacılara yayınlarda yapılan atıflar boyutuyla farkındalık sağlamada olumlu bir etki oluşturabileceği beklenmektedir. 


\section{LITERATÜRDE BİBLIYOMETRIKK ÇALIŞMALAR}

Literatürde ilk bibliyometrik çalışma Cole ve Eales tarafindan 1917 yılında ortaya konulmuştur. Söz konusu çalışmada; 1550-1860 yılları aralığında karşılaştırmalı anatomi alanında yayınlanan çalışmaların istatistiki bir analizi gerçekleştirilmiştir. $\mathrm{Bu}$ çalışmanın ardından 1923 yılında İngiliz Patent Ofisi'nde resmi bir kütüphaneci olan E.Wyndham Hulme tarafından tarih bilimi alanında istatistiki bir analiz gerçekleştirilmiştir. Daha sonra ise 1927 y1lında P.L.K. Gross ve E.M. Gross tarafindan Journal of the American Chemical Society' de yayınlanan makalelerin kaynakçalarının değerlendirildiği bir atıf analizi çalışması ortaya konulmuştur. Cole ve Eales ve Hulme, çalışmalarında atıflara değil bibliyografik özelliklere odaklanmıştır, bu anlamda Gross\&Gross'un yaptığı çalışma atıf analizi alanında ilk çalışma olarak kabul edilmektedir (Lawani, 1981: 295).

Türkiye' de ise bibliyometrik anlamda yapılan ilk çalışmanın 1970 yılında Özinönü tarafindan yayınlanan 'Growth in Turkish Positive Basic Sciences' olduğu kabul edilmektedir. Eserde astronomi, biyoloji, fizik, kimya, matematik, yer bilimleri alanlarındaki bilimsel verimliliğin ölçülmesi amaçlanmıştır. 1990 ve daha sonraki yıllarda da bu konuya ilişkin çalışmaların sayısında artış görülmeye başlanmıştır (Al, 2008: 10). Akademik dergilere ilişkin olarak ise ilgili alan yazında gerçekleştirilmiş olan çok sayıda çalışma yer almaktadır. $\mathrm{Bu}$ çalışmalardan bazılarını kapsam ve yöntemleri itibariyle şu şekilde ifade etmek mümkündür:

Hoffman ve Holbrook (1993) Journal of Consumer Research'de ilk 15 yılda yayınlanan makalelere ilişkin olarak bibliyometrik bir analiz gerçekleştirmiştir. Bu noktada ele alınan dergide en fazla yayın yapan 42 yazarın yayınları dikkate alınmıştır.

Alexander ve Mabry (1994) finans alanında yayınlanan birinci sınıf dergilerin alana yönelik göreli katkılarını belirlemek amacıyla bibliyometrik bir çalışma gerçekleştirmişlerdir.

Kalyane ve Sen (1995) çalışmalarında Journal of Oilseeds Research'de 1984-1992 yılları aralığında yayınlanan toplam 498 adet çalışmayı yazar sayısı, yazar verimliliği, anahtar kelimeler, atıf çeşitliliği, sayfa sayısı, kabul ve yayınlanma süresi arasındaki zaman dilimi gibi çeşitli kriterler doğrultusunda bibliyometrik açıdan analize tabi tutmuştur.

Phene ve Guisinger (1998) çalışmalarında Journal of International Business Studies' de 1981-91 yılları aralığında yayınlanan çalışmaları bibliyometrik özellikleri açısından değerlendirmeye alarak elde edilen bulgular doğrultusunda, yayın kuruluna derginin gelişim düzeyinin arttırılması hususunda neler yapılabileceğine dair birtakım önerilerde bulunmuştur.

Dalen ve Henkens (1999) çalışmalarında 1991-95 yılları aralığında demografi dergilerinde yayınlanan makaleleri, bilgi farkındalığına yaptıkları katkıyı araştırmak amacıyla bibliyometrik açıdan analiz etmişlerdir. Çalışmadan elde edilen sonuçlar, incelemeye alınan dergilerde yayınlanan makalelerin \%64'üne yayın yılını izleyen beş yıl içinde en az bir kez atıf yapıldı̆̆ını göstermiştir. 
Jacobs ve Ingwersen (2000) 1981-96 dönem aralığında yayın ve atıf trendlerini bibliyometrik açıdan incelemek amacıyla gerçekleştirdikleri çalışmalarında; Güney Afrika' da yer alan ve eğitim kalitesi, yayın sayısı, gelişim durumları açısından farklılık arz eden on üniversitede fizik, kimya, bitki ve hayvan bilimleri ve biyokimya/mikrobiyoloji alanlarında çalışan yazarların yayınlarını incelemişlerdir.

Al ve Tonta (2004) çalışmalarında Hacettepe Üniversitesi Kütüphanecilik bölümünde 1974-2002 yılları arasında yazılan 100 tane yüksek lisans ve doktora tezini bibliyometrik açıdan incelemeye almışlardır.

Hazarika (2005) Indian Journal of Forestry'de 2000-2002 yılları aralı̆̆ında yayınlanan çalışmaları bibliyometrik özellikleri açısından değerlendirmeye almıştır. Ele alınan 252 adet çalışmada toplamda 3798 adet atıf değerlendirmeye tabi tutmuşlardır.

Vassinen (2006) stratejik pazarlamaya ilişkin alan yazının özelliklerini belirlemek amacıyla gerçekleştirmiş olduğu çalışmasında 1986-2005 yılları aralığında olmak üzere 37 dergide yayınlanan 423 makaleyi bibliyometrik açıdan ele almıştır.

Al ve Coştur (2007) çalş̧malarında 1995 y1lından itibaren Social Science Citation Index' de taranan Türk Psikoloji Dergisi'nde 1995-2005 yılları arasında yayınlanan 118 makalenin bibliyometrik analizini gerçekleştirmiştir.

Birinci (2008) 1995 yllindan itibaren Science Citation Index ve Chemical Abstracts tarafindan taranan Turkish Journal of Chemistry dergisinde 1995-2007 yılları arasinda yayınlanan 861 tane makaleyi bibliyometrik açıdan ele almıştır.

Anyi ve diğerleri (2009) çalışmalarında 1998-2008 yılları aralığında yayınlanan ve 12 adet Sanat, İnsan ve Toplum Bilimleri alanı, 19 adet Medikal ve Sağlık Bilimleri alanı, 30 adet Bilim ve Teknoloji alanı ve 21 adet Kütüphane ve Bilişim Bilimi alanında yapılmış olmak üzere toplamda 82 adet çalı̧̧mayı incelemişlerdir.

Yalçın (2010) yayına başlama y1l 1989 olan Milli Folklor Dergisi'nde 2007-2009 yılları aralığında yayınlanan 174 makaleyi bibliyometrik özellikleri açısından incelemeye almıştır.

Wang ve Hu (2011) reklamcılık alanının temel özelliklerini bibliyometrik açıdan incelemeye aldıkları çalışmalarında 1990-2009 yılları arasında SSCI'da taranan pazarlama ve reklamcılık dergilerinde yayınlanan 39 makaleyi ele almış, 1801 tane atıf incelemesinde bulunmuşlardır.

Samiee ve Chabowski (2012) uluslararası pazarlama alanında 1999-2008 yılları aralığında yayınlanan makalelerin analizini gerçekleştirmeyi amaçladıkları çalışmalarında bibliyometrik analiz yöntemlerinden; açıklayıcı faktör analizi, hiyerarşik kümeleme analizi ve metrik çok boyutlu ölçekleme olmak üzere üç yöntemden yararlanmıştır.

Özel ve Kozak (2012) çalışmalarında 2000-2010 yılları arasında turizm pazarlaması alanında yürütülen Türkçe makaleleri bibliyometrik açıdan incelemeyi amaçlamış ve ele alınan makalelerde yer alan atıfların analizlerini gerçekleştirmiştir. 
Polat ve diğerleri (2013) Atatürk Üniversitesi İktisadi ve İdari Bilimler Dergisi'ni bibliyometrik olarak analiz etmeyi amaçladıkları çalışmalarında 2005-2012 yılları arasında toplamda 434 tane makaleyi analiz etmişlerdir.

Şakar ve Cerit (2013) çalışmalarında 1980-2012 yılları aralığında SSCI'da taranan ve konu başlığında 'pazarlama' kelimesi yer alan uluslararası yayınların bibliyometrik analizini gerçekleştirmiştir.

\section{YÖNTEM}

$\mathrm{Bu}$ çalışmada nitel araştırma yöntemlerinden bibliyometri tekniği kullanılmıştır. Bibliyometri kavramı 1969 yılında Pritchard tarafindan ortaya atılmıştır. Pritchard'ın istatistiksel biyografi kavramını yeniden tanımlama gereksinimi yeni bir nitel araştırma yönteminin doğmasına olanak sağlamıştır. Pritchard bibliyometri kavramını kitap ve diğer kaynakların özelliklerini belirlemede kullanılan matematiksel ve istatistiksel bir yöntem olarak tanımlamaktadır (Lawani, 1981: 294). Bibliyometrik teknikler zamanla önemli bir gelişme göstermiş; bir ülke, bir kurum veya bir yazar tarafindan yapılan katkıların analizinin yapılması, yapılan yayınların bilimsel alanda yaptığı katkının ölçülmesi, aynı yayın içerisinde bir kaynağa kaç kez atıf yapıldığının belirlenmesi şeklinde çeşitli analiz teknikleri ortaya çıkmıştır. Sözü edilen teknikler daha detaylı ve daha etkili bir ölçüm gerçekleştirme noktasında araştırmacılara yön göstermektedir. Nitel araştırma yöntemlerinden bibliyometri tekniği günümüzde birçok disiplinde uygulama alanı bulmaktadır (Okuba, 1997: 9):

- Tarih bilimi; araştırmacılar tarafindan elde edilen bulgular neticesinde şekillenen tarihi gelişmelere 1şık tutarak bilimsel disiplinlerin gelişimlerine olanak tanımaktadır.

- Sosyal bilimler; bilimsel literatürü incelemek suretiyle araştırmacıların bulgularını ve bağlantılarını desteklemektedir.

- Dokümantasyon; kütüphanelerin sahip olduğu dergi sayısını belirlemekte ve herhangi bir bilim dalının temel veya ikincil kaynaklarını ve çerçevesini oluşturan dergileri ortaya koymaktadır (Belli bir alanda sunulan bilginin \%50, \%80 veya \%90‘nını kapsayan dergi sayısını analiz etmektedir).

- Bilimsel politika; verimlilik ve bilimsel açıdan kalite düzeyini ölçen göstergeleri ortaya koymaktadır.

Bibliyometrik analiz; bilimsel araştırmaların gelişim düzeyini arttırma noktasında daha geniş bir perspektiften bakmaya olanak sağlayan, disiplinler arası temel bir dayanak olarak kabul edilmektedir (Samiee ve Chabowski, 2012: 369). Huang ve diğerleri bibliyometrik verilerin; ülkeleri, üniversiteleri, araştırma kurumlarını, dergileri, özel araştırma konularını ve çeşitli disiplinlerin özelliklerini belirleme ve değerlendirmede oldukça etkili bir yöntem olduğunu belirtmişlerdir (Huang ve diğerleri, 2006: 76).

Yaklaşık son birkaç on yıllık dönemde, nitel araştırma yöntemlerinden bibliyometrik analiz tekniği herhangi bir alandaki bilimsel gelişim düzeyini belirlemede önemli bir yöntem olarak karşımıza çıkmaktadır. Belli bir alandaki akademik gelişim düzeyini anlamada analizin odak noktası olarak yapılan çalışmaların özelliklerini detaylı olarak ele almak son derece 
önemlidir ve bu anlamda bibliyometrik analizlerin yaptığ diğerleri, 2010: 25). Bu çalışmada nitel araştırma yöntemlerinden bibliyometrik atıf analizi tekniği kullanılmıştır.

\section{BULGULAR VE DEĞERLENDİRME}

Herhangi bir bilim dalının bir ülkedeki mevcut durumu ve gelişmişlik düzeyi hakkında bilgi sahibi olma noktasında en önemli veri tabanlarından birinin, söz konusu alanda gerçekleştirilmiş olan çalışmaların olduğu ifade edilmektedir (Kozak, 2000: 16).Bu çalışmada muhasebe ve finans alanındaki gelişmeleri etkili bir şekilde yansıttığı kabul edilen Muhasebe ve Finansman Dergisi'nde 2005-2013 y1lları arasında yayınlanan makalelerin bibliyometrik profili farklı boyutlar açısından betimlenmiş ve toplamda 562 tane makale çalışmanın örneklemini oluşturmuştur. Dergide 2005 yılından 2014 yılına kadar toplamda 585 makale yayınlanmakla birlikte, çalışmalardan bazılarına ulaşılamaması nedeniyle 23 makale analiz kapsamı dışında tutulmuştur. Çalışma kapsamında ele alınan makalelere ilişkin elde edilen tüm bilgiler, Excel programına aktarılmış; tüm değerlendirmeler ve tablolar bu program aracılığıyla gerçekleştirilmiştir.

\subsection{Makale Sayılarının Yıllara Göre Dağılımı}

Yılda dört defa çıkarılan ve her yıl ortalama 62 makalenin yayınlandı̆̆ 1 Muhasebe ve Finansman Dergisi'ndeki makale sayılarının yıllar itibariyle dağılımı Grafik 1'de gösterilmiştir:

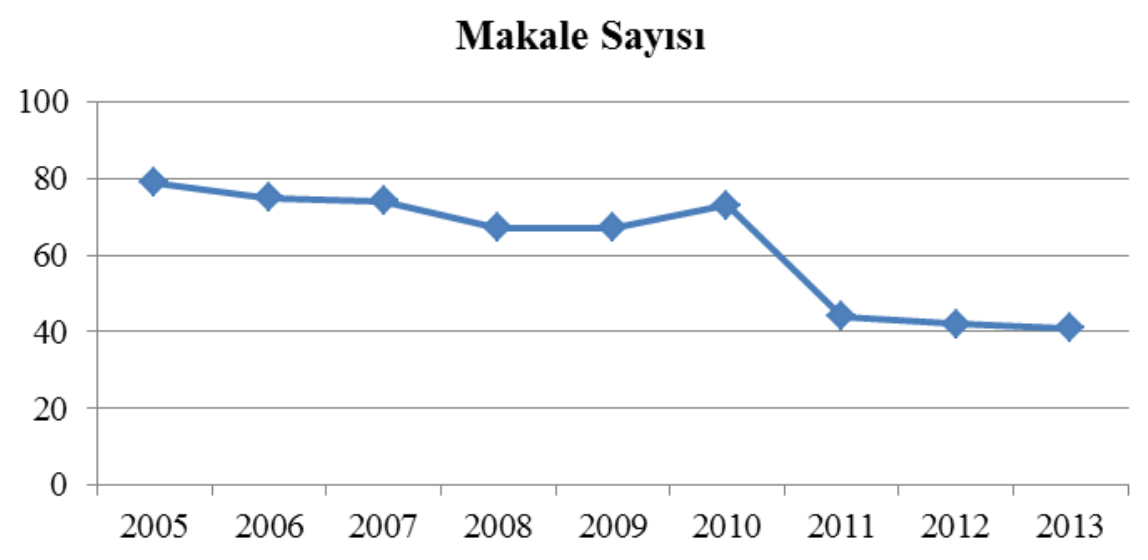

Grafik 1: Makale Sayılarının Yıllara Göre Dağılımı

2005-2013 yılları arasında toplam 36 sayıda 562 makale yayınlanmıştır. Grafik 1'e göre, en çok makalenin yayınlandığı yıl 2005 yılı (79), 2006 yılı (75), 2007 y1lı (74) ve 2010 y1lı (73) iken, en az makale 2013 yılında (41) yayınlanmıştır. 


\subsection{Yazar Sayısına Göre Dağılım}

Çalışma kapsamında ele alınan 562 makale 558 yazar tarafından yazılmıştır. Makale başına düşen yazar sayısı 1,01'dir. Ele alınan makalelerde söz konusu olan tek yazar ve çok yazarlılık durumu Grafik 2'de gösterilmiştir:

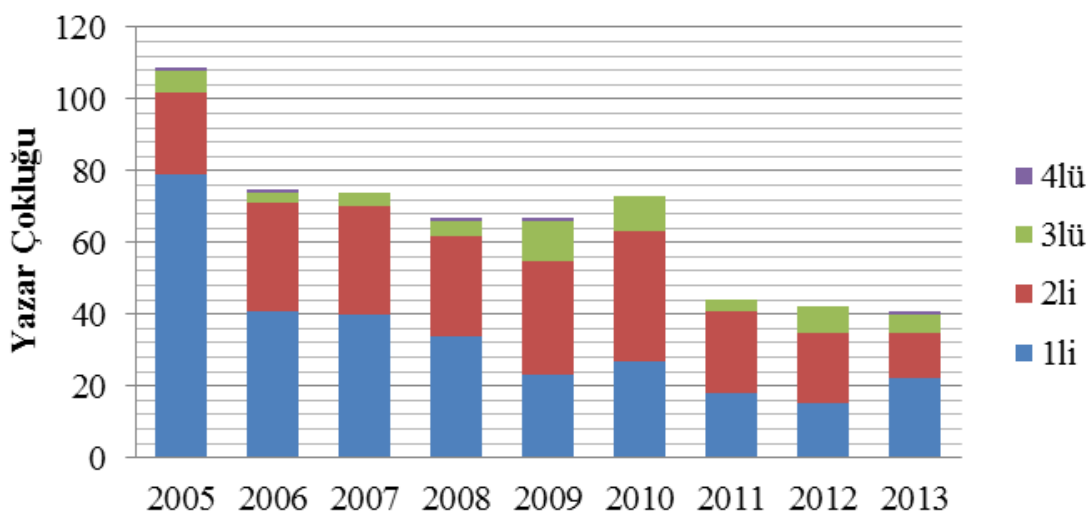

Grafik 2: Yazar Durumu

Dergide tek yazar tarafından yazılmış makale sayısı 2005 yılında; 79, 2006 y1lında 41, 2007 yılında 40, 2008 yılında 34, 2009 yılında 23, 2010 yilında 27, 2011 yilında 18, 2012 yilında 15 ve 2013 yılında 22 olmak üzere toplamda 299' dur. Toplamda 235 makale iki yazar tarafindan, 53 makale üç yazar tarafından ve 5 makale dört yazar tarafindan yazılmıştır. Bu noktada yazarların daha çok bireysel olarak yayın yapmayı tercih ettiklerini ifade etmek mümkündür.

\subsection{Yazar Profili}

Muhasebe ve Finansman Dergisi'nde 2005-2013 dönem aralığında yayınlanan toplam 562 makale, 558 yazar tarafından yazılmıştır. Ele alınan dönem aralığında yayınlanan tüm makaleler arasında Oktay Güvemli'nin yirmi, Sudi Apak'ın on dört, Mustafa A.Aysan ve Özer Ertuna'nın ise onar makale ile en verimli yazar kategorisinde yer aldığı belirlenmiştir. Diğer verimli yazarlar arasında ise; Adem Anbar, Ahmet Büyükşalvarcı, Ayten Ersoy ve Ümit Gücenme Gençoğlu yedişer, Cemal Elitaş, Famil Şamiloğlu, Fehmi Yıldız, Lale Karabıyık, Mehmet Gençtürk, Mehmet Özbirecikli, Muhsin Çelik ve Sezai Dumanoğlu altışar makale ile söz konusu kategoride yer almaktadır.

Tablo 1: Yazarların Verimliliğine Göre Dağılımı

\begin{tabular}{|l|c|l|}
\hline Yazar İsmi & Yayın Sayısı & Çalıştığı Kurum \\
\hline Oktay Güvemli & 20 & Marmara Üniversitesi \\
\hline Sudi Apak & 14 & Trakya Üniversitesi \\
\hline Mustafa A.Aysan & 10 & İstanbul Üniversitesi \\
\hline Özer Ertuna & 10 & Boğaziçi Üniversitesi \\
\hline Adem Anbar & 7 & Uludağ Üniversitesi \\
\hline Ahmet Büyükşalvarcı & 7 & Selçuk Üniversitesi \\
\hline Ayten Ersoy & 7 & Akdeniz Üniversitesi \\
\hline
\end{tabular}




\begin{tabular}{|l|l|l|}
\hline Ümit Gücenme Gençoğlu & 7 & Uludağ Üniversitesi \\
\hline Cemal Elitaş & 6 & Afyon Kocatepe Üniversitesi \\
\hline Famil Şamiloğlu & 6 & Niğde Üniversitesi \\
\hline Fehmi Yıldız & 6 & Trakya Üniversitesi \\
\hline Lale Karabıyıı & 6 & Uludağ Üniversitesi \\
\hline Mehmet Gençtürk & 6 & Mehmet Akif Ersoy Üniversitesi \\
\hline Mehmet Özbirecikli & 6 & Mustafa Kemal Üniversitesi \\
\hline Muhsin Çelik & 6 & Pamukkale Üniversitesi \\
\hline Sezai Dumanoğlu & 6 & Marmara Üniversitesi \\
\hline
\end{tabular}

Dergide yayınlanan 558 yazardan 379 tanesi $(\% 67,9)$ bir makale, 101 tanesi $(\% 18)$ iki makale, 41 tanesi $(\% 7,3) 3$ makale, 14 tanesi $(\% 2,5) 4$ makale, 8 tanesi $(\% 1,4) 6$ makale, 7 tanesi $(1,25) 5$ makale, 4 tanesi $(\% 0,72) 7$ makale, 2 tanesi $(\% 0,36) 10$ makale, 1 tanesi $(\% 0,18) 14$ makale ve diğer 1 tanesi ise $(\% 0,18) 20$ makale ile katkıda bulunmuşlardır.

\subsection{Yazarların Akademik Unvanlarına Göre Dağılımı}

Yazarların akademik unvanlarına ele alınan yıllar itibariyle bakıldığında; 2005 yılında Yrd. Doç unvanına sahip yazarların (52), 2006 yılında $Y r d$. Doç unvanına sahip yazarların (28), 2007 yılında Prof. unvanına sahip yazarların (35), 2008 yılında Yrd. Doç unvanına sahip yazarların (33), 2009 yılında Yrd. Doç unvanına sahip yazarların (47), 2010 yılında Yrd. Doç unvanına sahip yazarların (47), 2011 yılında Yrd. Doç unvanına sahip yazarların (33), 2012 yılında Yrd. Doç unvanına sahip yazarların (29) ve 2013 yılında Yrd. Doç unvanına sahip yazarların (32) çalışmalarının yer aldığı görülmüştür. Tüm yıllar göz önüne alındığında $Y r d$. Doç unvanına sahip yazarların daha çok katkıda bulunduğu sonucuna varılmıştır.

Tablo 2: Yazarların Akademik Unvanlarına Göre Dağılımı

\begin{tabular}{|l|c|c|c|c|c|c|c|c|c|}
\hline Unvan/Yıllar & $\mathbf{2 0 0 5}$ & $\mathbf{2 0 0 6}$ & $\mathbf{2 0 0 7}$ & $\mathbf{2 0 0 8}$ & $\mathbf{2 0 0 9}$ & $\mathbf{2 0 1 0}$ & $\mathbf{2 0 1 1}$ & $\mathbf{2 0 1 2}$ & $\mathbf{2 0 1 3}$ \\
\hline Öğretim Görevlisi(Öğr. Grv) & 3 & 6 & 5 & 10 & 13 & 14 & 8 & 8 & 8 \\
\hline Lisansüstü Öğrenci & 4 & 2 & 6 & 10 & 4 & 5 & 2 & 2 & 3 \\
\hline Profesör (Prof) & 24 & 27 & 35 & 15 & 22 & 17 & 6 & 7 & 2 \\
\hline Doçent (Doç) & 12 & 15 & 15 & 13 & 18 & 19 & 7 & 12 & 3 \\
\hline Yardımcı Doçent(Yrd. Doç) & 52 & 28 & 25 & 33 & 47 & 47 & 33 & 29 & 32 \\
\hline Doktor (Dr) & 9 & 13 & 7 & 7 & 4 & 8 & 5 & 2 & 8 \\
\hline Araştırma Görevlisi(Araş. Gör) & 12 & 20 & 15 & 13 & 14 & 19 & 12 & 17 & 9 \\
\hline Uzman & 0 & 1 & 5 & 3 & 1 & 0 & 0 & 0 & 0 \\
\hline Okutman & 0 & 1 & 0 & 0 & 0 & 0 & 0 & 0 & 0 \\
\hline Memur & 0 & 1 & 0 & 0 & 0 & 0 & 0 & 0 & 0 \\
\hline Bankac1 & 0 & 0 & 0 & 1 & 0 & 0 & 0 & 0 & 0 \\
\hline Avukat & 0 & 0 & 0 & 1 & 0 & 0 & 0 & 0 & 1 \\
\hline SMMM & 0 & 0 & 0 & 0 & 0 & 0 & 0 & 0 & 2 \\
\hline Muhasebe Tarihçisi & 1 & 1 & 0 & 0 & 1 & 0 & 0 & 0 & 0 \\
\hline
\end{tabular}

$Y r d$. Doç unvanını taşıyan yazarlardan sonra en fazla katkı yapan yazarların unvanları yıllar itibariyle değişiklik göstermekle birlikte, ağırlıklı olarak Prof (2005-2006-2008-2009) ve Araş. Gör (2011-2012-2013) unvanları olduğu sonucuna ulaşılmıştır. 


\subsection{Yazarların Çalıştıkları Kuruma Göre Dağılımı}

Dergide 2005-2013 yılları aralığında yayınlanan makalelerin yazarlarının 112 farklı kurumda görev yaptığı sonucuna ulaşılmıştır. Kurumlar dikkate alındığında; Marmara Üniversitesi 66, Uludağ Üniversitesi 43, Süleyman Demirel Üniversitesi 38, Sakarya Üniversitesi 35 ve Trakya Üniversitesi 35 makale ile dergiye en fazla katkı yapan ilk beş kurum arasında yer almıştır.

Tablo 3: Beş ve Daha Fazla Yayına Sahip Kurumlar

\begin{tabular}{|c|l|c|c|l|c|}
\hline Sıra & Kurum & Sayl & Srra & Kurum & Sayı \\
\hline $\mathbf{1}$ & Marmara Üniversitesi & 66 & $\mathbf{2 5}$ & İönü Üniversitesi & 11 \\
\hline $\mathbf{2}$ & Uludağ Üniversitesi & 43 & $\mathbf{2 6}$ & Niğde Üniversitesi & 10 \\
\hline $\mathbf{3}$ & Süleyman Demirel Üniversitesi & 38 & $\mathbf{2 7}$ & Mustafa Kemal Üniversitesi & 10 \\
\hline $\mathbf{4}$ & Sakarya Üniversitesi & 35 & $\mathbf{2 8}$ & Pamukkale Üniversitesi & 10 \\
\hline $\mathbf{5}$ & Trakya Üniversitesi & 35 & $\mathbf{2 9}$ & Fatih Üniversitesi & 10 \\
\hline $\mathbf{6}$ & Dokuz Eylül Üniversitesi & 31 & $\mathbf{3 0}$ & Mehmet Akif Ersoy Üniversitesi & 10 \\
\hline $\mathbf{7}$ & Akdeniz Üniversitesi & 31 & $\mathbf{3 1}$ & Okan Üniversitesi & 10 \\
\hline $\mathbf{8}$ & Anadolu Üniversitesi & 29 & $\mathbf{3 2}$ & Boğaziçi Üniversitesi & 8 \\
\hline $\mathbf{9}$ & Karadeniz Teknik Üniversitesi & 25 & $\mathbf{3 3}$ & Gaziosmanpaşa Üniversitesi & 8 \\
\hline $\mathbf{1 0}$ & Bilecik Üniversitesi & 25 & $\mathbf{3 4}$ & Mersin Üniversitesi & 8 \\
\hline $\mathbf{1 1}$ & İstanbul Üniversitesi & 24 & $\mathbf{3 5}$ & Yalova Üniversitesi & 8 \\
\hline $\mathbf{1 2}$ & Çanakkale Üniversitesi & 24 & $\mathbf{3 6}$ & Kırıkkale Üniversitesi & 7 \\
\hline $\mathbf{1 3}$ & Dumlupınar Üniversitesi & 18 & $\mathbf{3 7}$ & Yeditepe Üniversitesi & 7 \\
\hline $\mathbf{1 4}$ & Afyon Kocatepe Üniversitesi & 18 & $\mathbf{3 8}$ & Harran Üniversitesi & 7 \\
\hline $\mathbf{1 5}$ & Selçuk Üniversitesi & 18 & $\mathbf{3 9}$ & Gaziantep Üniversitesi & 6 \\
\hline $\mathbf{1 6}$ & Adnan Menderes Üniversitesi & 17 & $\mathbf{4 0}$ & Osmangazi Üniversitesi & 6 \\
\hline $\mathbf{1 7}$ & Gazi Üniversitesi & 16 & $\mathbf{4 1}$ & Atatürk Üniversitesi & 6 \\
\hline $\mathbf{1 8}$ & Zonguldak Karaelmas Üniversitesi & 16 & $\mathbf{4 2}$ & Bozok Üniversitesi & 6 \\
\hline $\mathbf{1 9}$ & Celal Bayar Üniversitesi & 16 & $\mathbf{4 3}$ & Başkent Üniversitesi & 5 \\
\hline $\mathbf{2 0}$ & Muğla Sttkı Koçman Üniversitesi & 15 & $\mathbf{4 4}$ & Kadir Has Üniversitesi & 5 \\
\hline $\mathbf{2 1}$ & Kocaeli Üniversitesi & 14 & $\mathbf{4 5}$ & Erzincan Üniversitesi & 5 \\
\hline $\mathbf{2 2}$ & Beykent Üniversitesi & 14 & $\mathbf{4 6}$ & İstanbul Ticaret Üniversitesi & 5 \\
\hline $\mathbf{2 3}$ & Balıkesir Üniversitesi & 12 & $\mathbf{4 7}$ & Kafkas Üniversitesi & 5 \\
\hline $\mathbf{2 4}$ & Çukurova Üniversitesi & 12 & $\mathbf{4 8}$ & Nevşehir Üniversitesi & 5 \\
\hline
\end{tabular}

Dergide yayınlanan makalelerin yazarlarının görev yaptı̆̆ 1 kurumların 8'i yabancı, 104 tanesi ise yerlidir. Ayrıca Maliye Bakanlığı, İstanbul Menkul Kıymetler Borsası, Sermaye Piyasası Kurulu, Bankacılık Düzenleme ve Denetleme Kurulu, Merkezi Kayıt Kurulu, Türkiye Muhasebe Uzmanları Derneği ve çeşitli özel sektör kuruluşlardan da katkıda bulunan yazarların da yer aldığı görülmüştür. Ayrıca yazarların bağlı bulundukları kurum içinde mi, yoksa farklı üniversitelerle işbirliği yoluna mı gittiği konusunda; daha çok aynı kurum içerisinde yapılan yayın sayısının ağırlık kazandığg sonucuna varılmıştır.

Beş yayının altında katkı yapan diğer yerli ve yabancı üniversiteleri ise şu şekilde sıralayabiliriz: Cumhuriyet, Yıldız Teknik, Bahçeşehir, Kilis, Erciyes, Gümüşhane, İstanbul Kültür, Koç, Uşak, Hacettepe, Aksaray, Hitit, Adıyaman, Dicle, Çankırı, Kahramanmaraş Sütçü İmam, Rize, Şırnak, Bilecik Şeyh Edebali, Yıldırım Beyazıt, Ankara, Galatasaray, 
İstanbul Aydın, TOBB, İstanbul Teknik, Artvin Çoruh, Ege, Düzce, Namık Kemal, On Dokuz Mayıs, Yüzüncü Y1l, Karamanoğlu Mehmet Bey, Kırklareli, Bitlis Eren, Bülent Ecevit Üniversitesi, Academy of Economic Studies of Bucharest, Massachusetts Institute, Yale University, Case Western Reserve University, Cardiff Business School, Autonomous University of Madrid, California State Polytechnic University, The Norwegian School of Economics and Business Administration.

\subsection{Makalelerin Konularına Göre Dağılımı}

Dergide 2005-2013 yılları aralığında yayınlanan 562 makalenin konuları, makalelerde kullanılan anahtar kelimeler aracılığıyla belirlenmiş ve Tablo 4'de gösterilmiştir:

Tablo 4: Makalelerin Konu Dağılımı

\begin{tabular}{|l|c|l|c|}
\hline Konu & Sayı & Konu & Sayı \\
\hline Finansal Performans & $\mathbf{6 6}$ & Kurumsal Yönetim & $\mathbf{1 4}$ \\
\hline Kamu Ekonomisi & $\mathbf{5 3}$ & Yabancı Yatırımlar & $\mathbf{1 2}$ \\
\hline Finansal Piyasalar & $\mathbf{5 2}$ & Basel Düzenlemeleri & $\mathbf{1 2}$ \\
\hline Muhasebe Eğitimi & $\mathbf{4 1}$ & Maliyet Muhasebesi & $\mathbf{1 0}$ \\
\hline Maliyetleme Yöntemleri & $\mathbf{3 7}$ & Finansman Sorunları & $\mathbf{1 0}$ \\
\hline Denetim & $\mathbf{3 5}$ & Davranışsal Finans & $\mathbf{7}$ \\
\hline Muhasebe Mesleği & $\mathbf{3 4}$ & Hile Denetimi & $\mathbf{7}$ \\
\hline Muhasebe Standartları & $\mathbf{3 3}$ & Çevre Muhasebesi & $\mathbf{7}$ \\
\hline Muhasebe Tarihi & $\mathbf{2 3}$ & Sermaye Yapısı Kararları & $\mathbf{4}$ \\
\hline Finansal Krizler & $\mathbf{2 2}$ & Finansal Başarısızlık & $\mathbf{2}$ \\
\hline Uluslar arası Ekonomi & $\mathbf{2 1}$ & Entelektüel Sermaye & $\mathbf{2}$ \\
\hline Muhasebe Bilgi Sistemleri & $\mathbf{1 9}$ & Yönetim Muhasebesi & $\mathbf{2}$ \\
\hline Türev Piyasalar & $\mathbf{1 9}$ & Sosyal Sorumluluk Muhasebesi & $\mathbf{1}$ \\
\hline Risk Yönetimi & $\mathbf{1 6}$ & Adli Muhasebe & $\mathbf{1}$ \\
\hline
\end{tabular}

Sınıflandırma işleminde 2003 tane anahtar kelime kullanılmıştır. Makale başına düşen anahtar kelime sayısı ise 3,56'dır. Elde edilen konu başlıklarından en fazla makale \% 11,7 ile finansal performans alanında yayınlanmıștır. Daha sonra \% 9,4 ile kamu ekonomisi alanına ilişkin makaleler gelmekte, üçüncü sırada ise \% 9,3 ile finansal piyasalara ilişkin yazılan makaleler yer almaktadır. Finansal başarısızlık, entelektüel sermaye, yönetim muhasebesi, sosyal sorumluluk muhasebesi ve adli muhasebe konularına ilişkin makale sayılarının ise daha az olduğu görülmektedir.

\subsection{Makalelerde Kullanılan Araştırma Yaklaşımları}

Ele alınan dönem aralığında yayınlanan çalışmalarda benimsenen araştırma yaklaşımlarının dağılımı yıllar itibariyle Grafik 3'de gösterilmiştir: 
Grafik 3: Tercih Edilen Araştırma Yaklaşımlarının Dağılımı

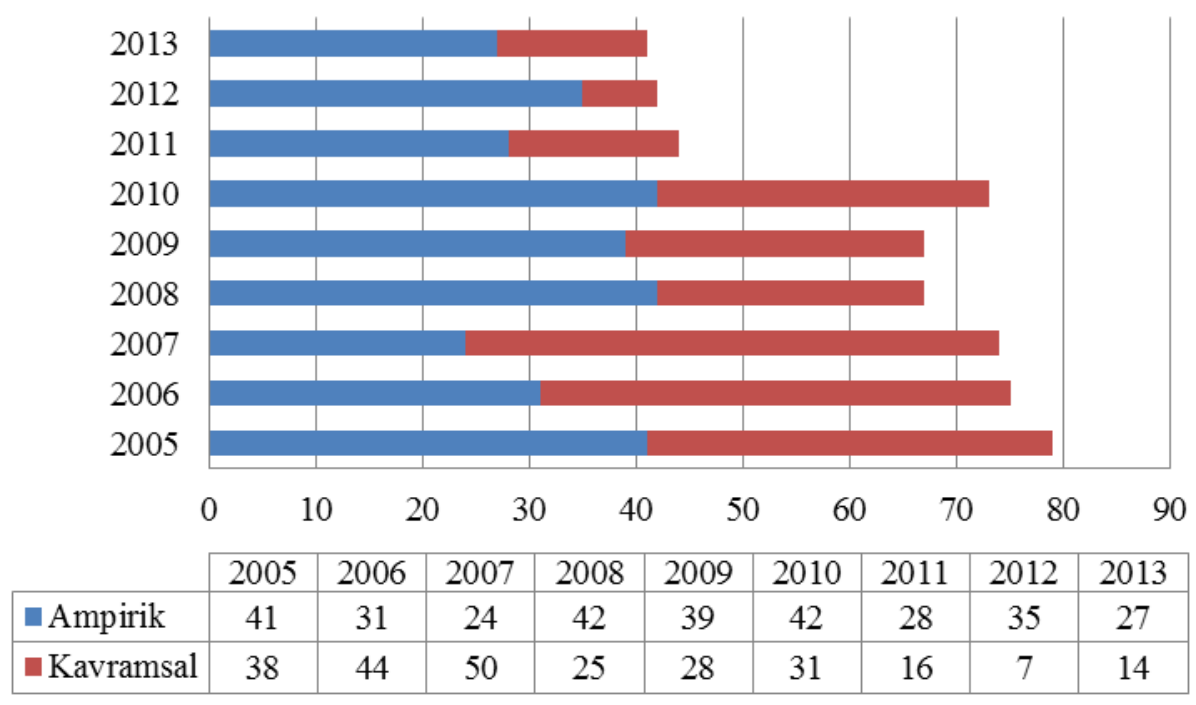

Makalelerde tercih edilen araştırma yaklaşımları; yapılan çalışmalar hakkında bilgi sahibi olunmasına olanak tanımakla birlikte, bir ülkedeki bilimsel çalışmaların düzeyi hakkında da somut sonuçlara ulaşılması noktasında katkı sağlamaktadır (Kozak, 1994: 29). İncelemeye alınan 562 makalenin 309'u (\%54,98) ampirik, 253 tanesi $(\% 45,02)$ ise kavramsal yaklaşımı tercih etmiştir.

\subsection{Makalelerin Sayfa Sayılarına Göre Dağılımı}

Dergide 2005-2013 yılları arasında yayınlanan 562 makaleden; 334 makalenin en fazla 10-17 sayfa aralığında yazıldığı, 138 makalenin 2-9 sayfa aralığında yazıldığı, 82 makalenin 18-25 sayfa aralığında yazıldığı ve 8 makalenin 26'nın üstünde bir sayfa uzunluğu ile yazıldı̆̆ı sonucuna varılmıştır.

Grafik 4: Sayfa Sayılarının Yıllar İtibariyle Dağılımı

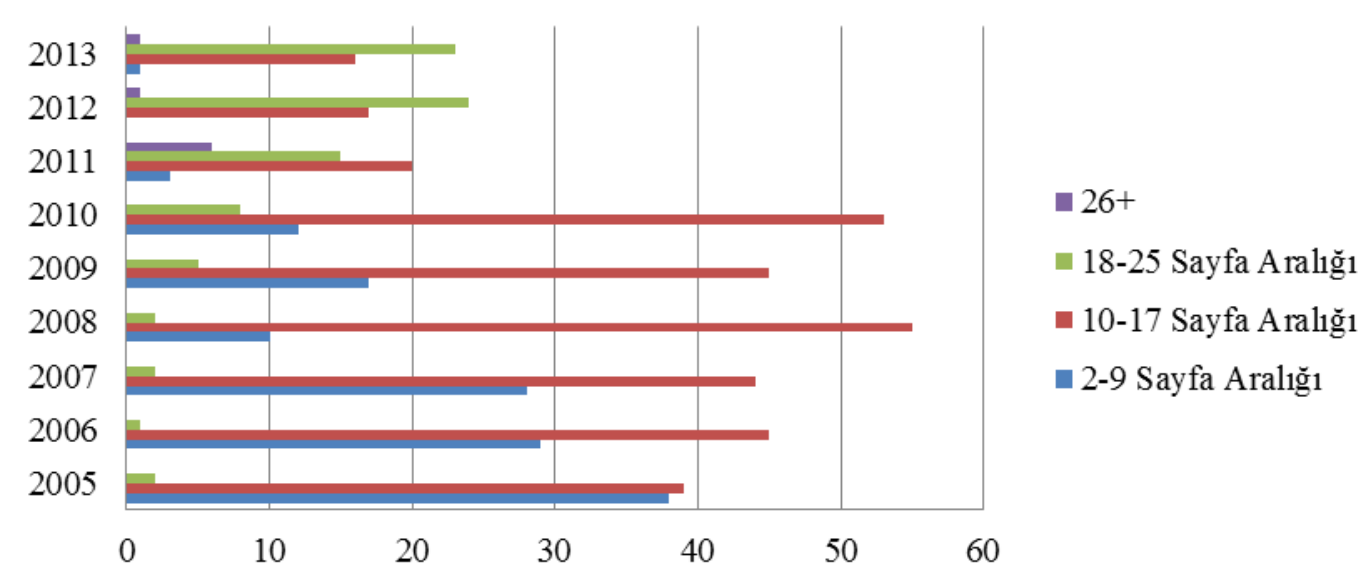

Ele alınan dönem aralığında toplam sayfa uzunluğu 2005 yılında 763, 2006 yılında 769, 2007 y1lında 775, 2008 yılında 810, 2009 y1lında 812, 2010 y1lında 943, 2011 y1lında 771, 
2012 y1lında 760 ve 2013 yılında ise 745 olmak üzere toplamda $7148^{\prime}$ dir. En az 2 ve en fazla 38 sayfa olmak üzere bir makalenin ortalama sayfa uzunluğu ise 12,72'dir.

\subsection{Makalelerdeki Yerli ve Yabancı Kaynak Sayılarının Dağılımı}

Yerli ve yabancı kaynak kullanımına bakıldığında; yabancı kaynakların daha fazla tercih edildiği sonucuna varılmıştır:

Grafik 5: Kaynakçada Kullanılan Yerli ve Yabancı Kaynakların Dağılımı
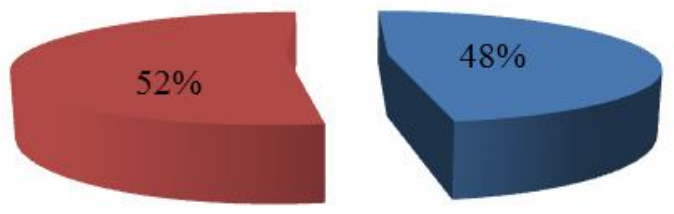

\section{- Yerli Kaynak}

- Yabanc1 Kaynak

Ele alınan dönem aralığında yayınlanan 562 makalede yararlanılan toplam yerli ve yabancı kaynakların kullanımına bakıldığında; yerli kaynak sayısının 2005 yılında 581, 2006 y1lında539, 2007 y1linda 586, 2008 y1lında 571, 2009 yılında 705, 2010 y1linda 797, 2011 yılında 476, 2012 yılında 482, 2013 yılında 407 olmak üzere toplamda 5144, yabancı kaynak sayısinın ise 2005 yılında 488, 2006 yılında 693, 2007 y1lında 657, 2008 y1lında 644, 2009 y1lında 550, 2010 y1linda 768, 2011 y1lında 708, 2012 y1lında 565 ve 2013 y1lında 604 olmak üzere toplamda 5677 tane olduğu görülmüştür.

\subsection{Kitaplara Yapılan Atıf Sayılarının Dağılımı}

Dergide ele alınan dönem aralığında yayınlanan makalelerin kaynakçasında kullanılan kitap sayılarının dağılımı Grafik 6'da verilmiştir:

Grafik 6: Kaynakçada Kullanılan Kitap Sayılarının Yıllara Göre Dağılımı

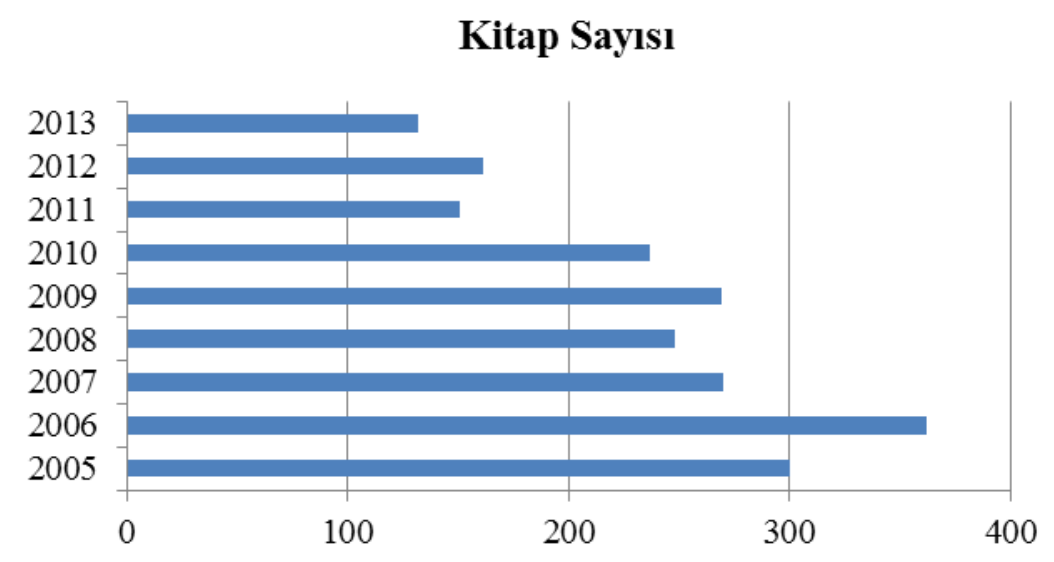

Grafik 6'ya bakıldığında; 2005 yılına ilişkin yayınlanan makalelerin kaynakçasında 300, 2006 y1lında 362, 2007 y1lında 270, 2008 y1lında 248, 2009 y1lında 269, 2010 y1lında 
237, 2011 yılında 151, 2012 yılında 161 ve 2013 yılında ise 132 kitaptan yararlanıldı̆̆ 1 görülmektedir. Tüm yıllar göz önüne alındığında ise toplamda 2130 kitaptan yararlanıldı̆̆ 1 anlaşılmaktadır.

\subsection{Dergilere Yapılan Atıf Sayılarının Dağılımı}

Dergide ele alınan dönem aralığında yayınlanan makalelerin kaynakçasında kullanılan dergi sayılarının dağılımı Grafik 7'de verilmiştir:

Grafik 7: Kaynakçada Kullanılan Dergi Sayılarının Yıllara Göre Dağılımı

\section{Dergi Sayısı}

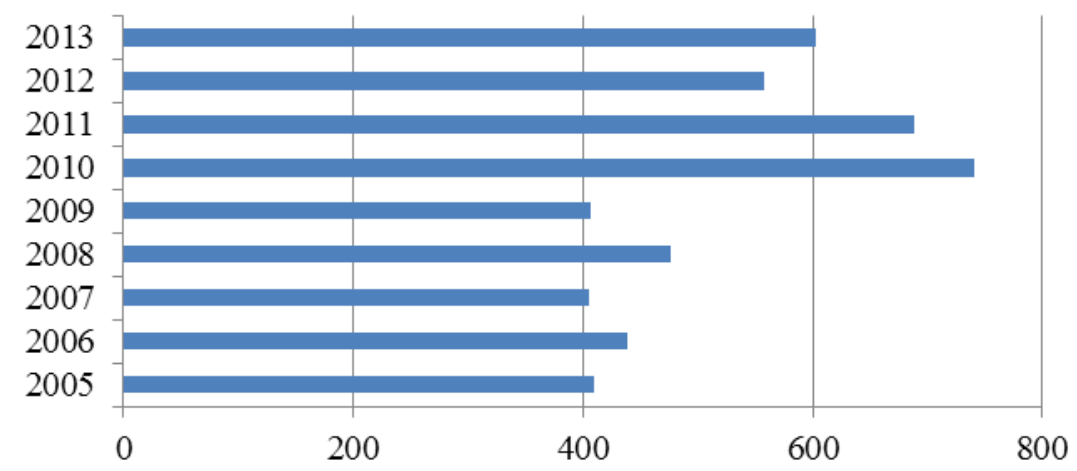

Ele alınan dönem aralığında yayınlanan makalelerde dergiye yapılan atıf sayıları; 2005 y1lı için 409, 2006 y1lı için 438, 2007 y1lı için 405, 2008 yılı için 477, 2009 y1lı için 407, 2010 y1lı için 741, 2011 y1lı için 688, 2012 yılı için 558 ve 2013 yılı için ise 603 olarak gerçekleşmiştir. Dergiye en fazla atıf yapılan yıl 2010 yılı olduğu görülmekle birlikte, toplamda 4726 atıf söz konusu olduğu görülmektedir.

\subsection{Bildirilere Yapılan Atıf Sayılarının Dağılımı}

Dergide ele alınan dönem aralığında yayınlanan makalelerin kaynakçasında kullanılan bildiri sayılarının dağılımı Grafik 8'de verilmiştir:

Grafik 8: Kaynakçada Kullanılan Dergi Sayılarının Yıllara Göre Dağılımı

\section{Bildiri Sayısı}

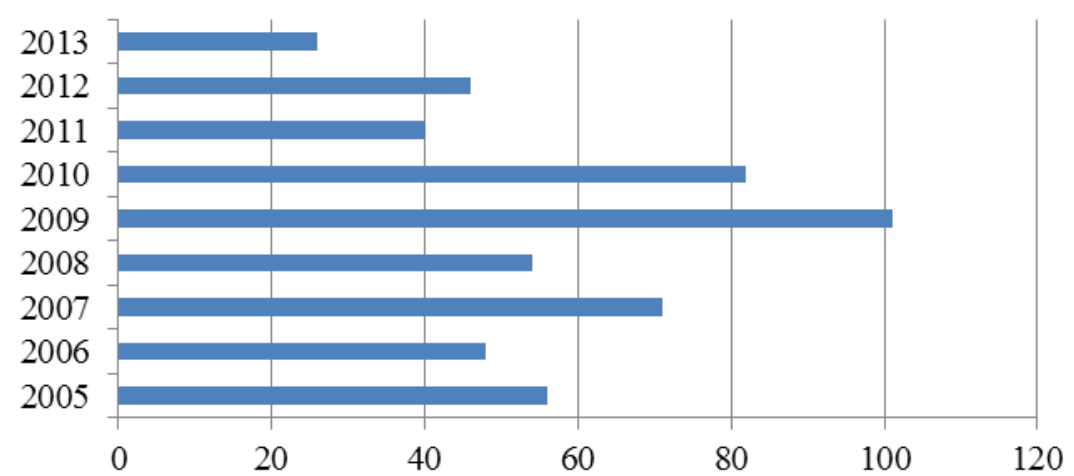


Grafik 8'e bakıldığında; bildiriye yapılan atıf sayısı 2005 yılında 56, 2006 yılında 48, 2007 y1lında 71, 2008 y1lında; 54, 2009 yılında 101, 2010 yılında 82, 2011 yılında 40, 2012 yılında 46 ve 2013 yılında 26 olarak gerçekleşmiştir. 562 makale içerisinde bildiriye yapılan toplam atıf sayıs 524 'dir.

\subsection{Diğer Kaynaklara Yapılan Atıf Sayılarının Dağılımı}

Dergi, kitap ve bildiri dışında elektronik kaynaklar, tez, kurum raporu, yönetmelik, gazete gibi çeşitli kaynaklara yapılan atıf sayılarının dağılımı Grafik 9'da gösterilmiştir:

Grafik 9: Kaynakçada Kullanılan Dergi Sayılarının Yıllara Göre Dağılımı

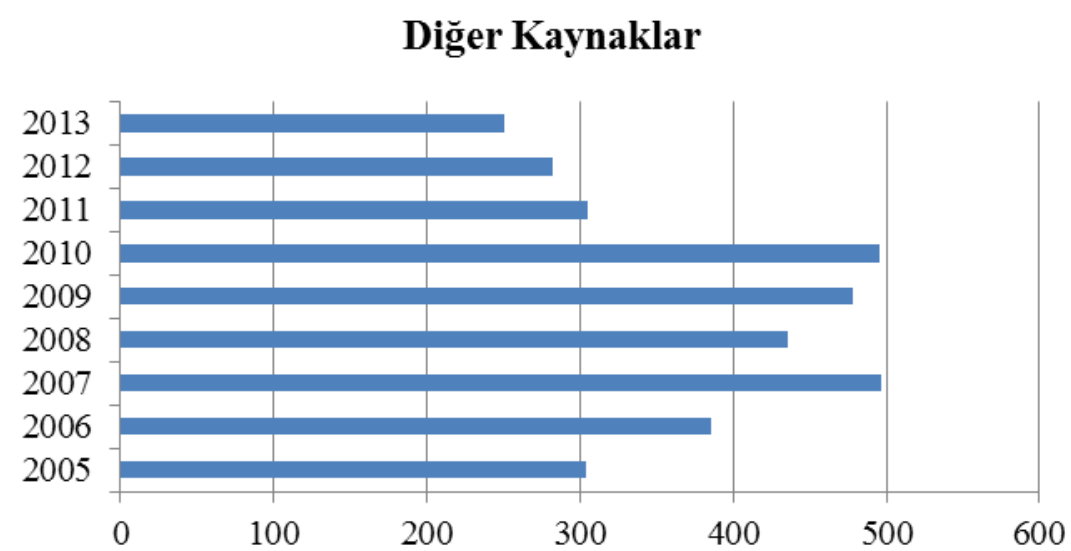

Grafik 9 incelendiğinde; 2005 yılında 304, 2006 yılında 385, 2007 yılında 497, 2008 y1lında 436, 2009 y1lında 478, 2010 y1lında 495, 2011 y1lında 305, 2012 y1lında 282 ve 2013 yılında 250 olmak üzere toplamda 3432 diğer kaynaktan yararlanıldığı anlaşılmaktadır.

Ele alınan dokuz yıllık dönemde yayınlanan 562 makalenin künyelerinden elde edilen veriler ışığında; kitap, dergi, bildiri ve diğer kaynaklara yapılan atıfların dağılımı Grafik 10’da gösterilmiştir:

Grafik 10: Atıf Yapılan Kaynak Türlerinin Dağılımı

\section{Kaynak Sayısı}

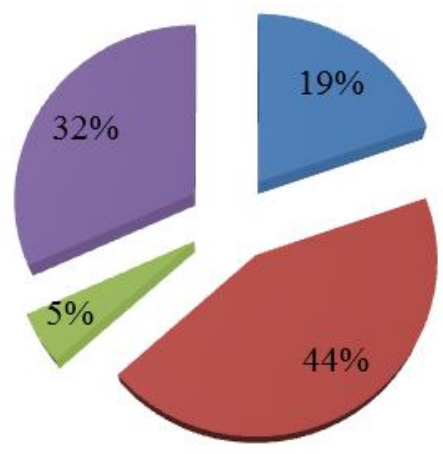

Kitap

Dergi

Bildiri

Diğer 
Grafik 10 incelendiğinde; yapılan makalelerde en fazla yararlanılan kaynağın \%44 ile dergiler olduğu görülmektedir. Daha sonra bu sırayı \%32 ile diğer kaynaklar, \%19 ile kitaplar ve \%5 ile bildirilerin takip ettiği sonucuna ulaşılmıştır.

\subsection{4. Özatıf Sayılarının Dağılımı}

Özatıf, makale yazarlarının kendi çalışmalarına yaptıkları atıf durumunu ifade etmektedir. Söz konusu atıf türü; doğal ve kabul edilebilir bir kavram olarak kabul edilmesinin yanı sıra, yazarların kendi bilimsel otoritelerini oluşturmak veya önceki çalışmalarını ön plana çıkarmak amacıyla başvurdukları bir yöntem olarak da kabul edilmektedir (Aksnes, 2003: 236).

Grafik 11: Özatıf Sayılarının Yıllara Göre Dağılımı

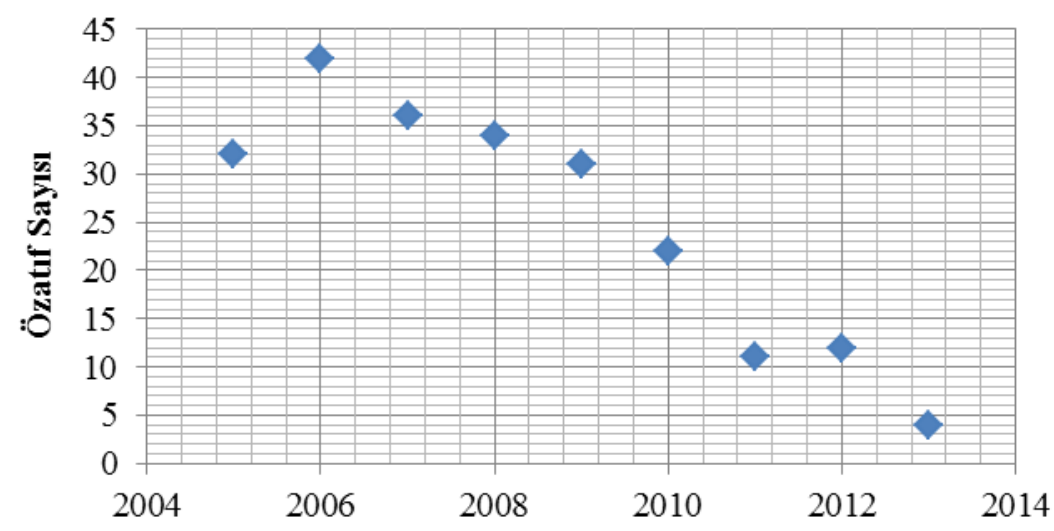

Yazarların kendilerine yaptıkları atıf sayıları 2005 yılında 32, 2006 yılında 42, 2007 y1lında 36, 2008 y1lında 34, 2009 y1lında 31, 2010 y1lında 22, 2011 y1lında 11, 2012 y1lında 12 ve 2013 y1lında 4 olmak üzere toplam 224 tane özatıf mevcuttur.

\subsection{Dergiye Yapılan Atıf Sayılarının Dağılımı}

Muhasebe ve Finansman Dergisi; muhasebe ve finans alanında yüksek düzeyde farkındalığa sahip dergilerden biri olarak kabul edilmektedir. Bu noktada dergide yayınlanan makalelerde dergiye atıfta bulunulması derginin başarı performanslarından biri olarak görülmektedir:

Grafik 12: Dergiye Atıf Sayılarının Yıllara Göre Dağılımı

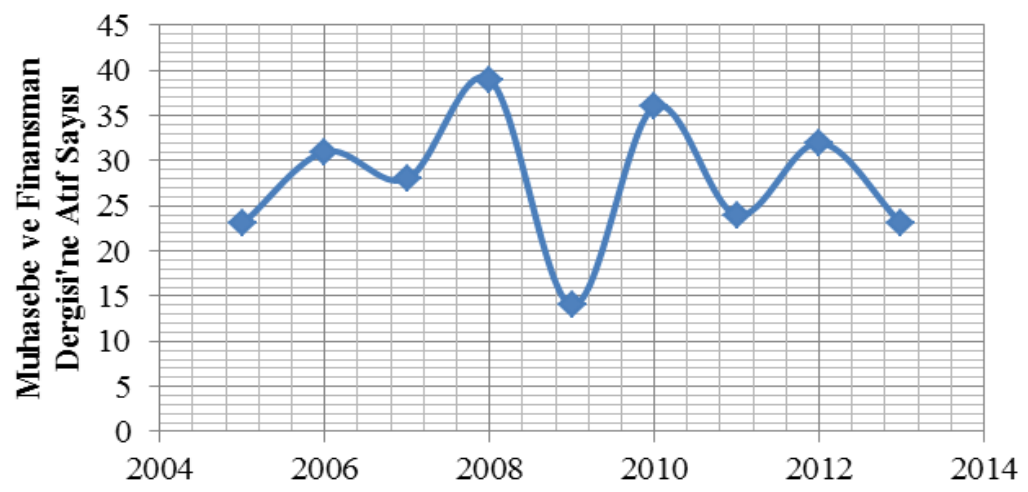


Grafik 12'den anlaşılacağı üzere; dergiye yapılan atıf sayısı 2005 yılında 23, 2006 y1linda 31, 2007 y1lında 28, 2008 yilında 39, 2009 yilında 14, 2010 yilında 36, 2011 yilında 24, 2012 yilında 32, 2013 y1lında ise 23 olmak üzere toplamda 250 tanedir.

\section{SONUÇ VE ÖNERILLER}

$\mathrm{Bu}$ çalışma ile Muhasebe ve Finansman Dergisi'nde yayın yapan yazarların profili, konu açısından yönelimleri, atıf yapılan kaynak türleri gibi çeşitli özellikler ele alınarak derginin bibliyometrik atıf profili ortaya koyulmaya çalışılmıştır. Bibliyometrik analiz herhangi bir alana ilişkin yayınlanmış çeşitli kaynakların gelişim düzeyinin tespit edilmesi açısından önemli bir yere sahiptir. Elde edilen bibliyometrik bulgular; incelemeye alınan bilim dalındaki gelişim düzeyinin, araştırmacıların odak noktalarının ve alanın güçlü veya zayıf yönlerinin tespit edilmesi noktasında katkı sağlamaktadır. İlgili alan yazına bakıldığında da; söz konusu nitel araştırma tekniğini kullanarak çeşitli disiplinlerdeki çalışmaları ele alan pek çok çalışmaya rastlamak mümkündür (Hoffman ve Holbrook; 1993, Alexander ve Mabry; 1994, Dalen ve Henkens; 1999, Jacobs ve Ingwersen; 2000, Al ve Tonta; 2004, Vassinen; 2006, Al ve Coştur; 2007, Birinci; 2008, Yalçın; 2010, Wang ve Hu; 2011, Samiee ve Chabowski; 2012, Özel ve Kozak; 2012, Polat vd.; 2013 ve Şakar ve Cerit; 2013).

Çalışmada 2005-2013 yılları arasında dergide 562 tane makale yayınlanmış ve söz konusu makalelere 558 yazar ile toplamda 112 kurum tarafindan katkı sağlanmıştır. Ele alınan dokuz yıllık dönemde toplam makale sayfa sayısı 7148 iken, bir makalenin ortalama sayfa uzunluğu ise 12,72 'dir.

En fazla katkı yapan kurumlar arasında Marmara, Trakya ve İstanbul Üniversiteleri yer alırken, makale başına düşen ortalama yazar sayısı 1,01 olduğu görülmüştür. Tüm yıllar göz önüne alındığında Yrd. Doç unvanına sahip yazarların çoğunlukta olduğu, daha sonra ise Prof. ve Araş. Gör unvanlarının yer aldığı sonucu elde edilmiştir.

Çok yazarlılık durumuna bakıldığında; genellikle bireysel çalışmalara yer verildiği, birden fazla yazarlı çalışmalarda ise yazarların kurum içi çalışmalara ağırlık verdiği sonucuna varılmıştır. Toplamda 299 makale tek yazar, 235 makale iki yazar, 53 makale üç yazar ve 5 makale dört yazar tarafından yazılmıştır.

Çalışmalarda ağırlıklı olarak finansal performans, kamu ekonomisi ve finansal piyasalara ilişkin konulara yer verilmiş ve ağırlıklı olarak ampirik araştırma yaklaşımları tercih edilmiştir.

Dergide yayınlanan makalelerde toplamda 10.812 kaynağa atıf yapılmış, atıfların \% 44'ü dergiler, \% 19'u kitaplar, \% 5'i bildiriler ve \% 32'si diğer kaynaklar şeklinde gruplanmıştır. Özatıf ve dergiye yapılan atıf sayıları dikkate alındığında ise; özatıf sayılarının toplamda 224, dergiye yapılan atıfların ise 250 olduğu görülmüş̧ür. Ayrıca yerli ve yabanc1 
kaynak dağılımına bakıldığında yerli kaynakların \% 52 oranında yerli, \% 48 oranında ise yabancı kaynaktan yararlanıldığı sonucuna varılmıştır.

Son olarak araştırmaya dâhil edilen makalelerin yazım diline bakıldığında; toplam 562 makaleden yalnızca 11 tanesinin yazım dilinin İngilizce olduğu saptanmıştır. Bu bağlamda yayınlanan makalelerde her ne kadar İngilizce özetlere yer verilmiş olsa da, dergideki yayınların uluslararası düzeyde araştırmacılar tarafından incelenebilirliğini ve dergiye atıf sayısını arttırma açısından bu konuya dikkat gösterilmesinde fayda vardır. Ayrıca ele alınan çalışmalara katkı yapan yazarların bağlı bulundukları 112 kurumun 104'ünün Türkiye'deki üniversite ve kurumlardan, geri kalan 8'inin ise yurtdışındaki kurumlardan oluştuğu gözlenmiştir. Bu noktada yayın dilini de, üzerinde durulması gereken bir unsur olarak ifade etmek mümkündür.

\section{KAYNAKLAR}

Aksnes, Dag W (2003), “A Macro Study of Self-Citation”, Scientometrics, Cilt: 56, Sayı: 2, ss. $235-246$.

Al, Umut (2004), “Bilimsel Yayınların Değerlendirilmesi: h-endeksi ve Türkiye' nin Performansı", Bilgi Dünyası, Cilt: 9, Sayı: 2, ss. 263-285.

Al, Umut - Tonta, Yaşar (2004), “Atıf Analizi: Hacettepe Üniversitesi Kütüphanecilik Bölümü Tezlerinde Atıf Yapılan Kaynaklar”, Bilgi Dünyası, Cilt: 5, Sayı: 1, ss. 19-47.

Al, Umut - Coştur, Recai (2007), “Türk Psikoloji Dergisi’ nin Bibliyometrik Profili”, Türk Kütüphaneciliği Dergisi, Cilt: 21, Say1: 2, ss. 142-163.

Al, Umut (2008), Türkiye'nin Bilimsel Yayın Politikası: Atıf Dizinlerine Dayalı Bibliyometrik Bir Yaklaşım”, Doktora Tezi, Ankara Üniversitesi, Ankara.

Alexander, John, C- Mabry, Rodney H (1994), "Relative Significance of Journals, Authors and Articles Cited in Financial Research", The Journal of Finance, Cilt: 49, Say1: 2, ss. 697-712.

Anyi, Kevin Wan Utap, Awang Ngah Zainab ve N. B. Anuar. (2009), "Bibliometric Studies on Single Journals: A Review”, Malaysian Journal of Library \& Information Science, Cilt: 14, Say1: 1, ss. 17-55.

Birinci, Hatice Gülşen (2008), “Turkish Journal of Chemistry’ nin Bibliyometrik Analizi”, Bilgi Dünyas1, Cilt: 9, Sayı: 2, ss. 348-369.

Dalen, Hendrik P. Van - Henkens, Kene (1999), "How Influential Are Demography Journals?", Population and Development Review, Cilt: 25, Say1: 2, ss.229-251.

Hazarika, Tilak. (2005). "Information Use Pattern of Indian Forestry Scientists: A Bibliographic Study", Annals of Library and Information Studies, Cilt: 52, Say1: 2, ss. 68-75. 
Heberger, E. Anne - Christie, A. Christina - Alkin, C. Marvin (2010), "A Bibliometric Analysis of the Academic Influences of and on Evaluation Theorists' Published Works", American Journal of Evaluation, Cilt: 31, Sayl: 1, ss. 24-44.

Hoffman, Donna L -Holbrook, B. Morris (1993), "The Intellectual Structure of Consumer Research: A Bibliometric Study of Author Cocitations in the First 15 Years of the Journal of Consumer Research", Journal of Consumer Research, Cilt: 19, Sayı: 4, ss. 505-517.

Huang, Ya-Li - Ho, Yuh-Shan - Chuang, Kun-Yang (2006), "Bibliometric Analysis of Nursing Research in Taiwan 1991-2004", Journal of Nursing Research, Cilt: 14, Say1: 1 , ss. 75-81.

Jacobs, Daisy -Ingwersen, Peter (2000), "A Bibliometric Study of the Publication Patterns in the Sciences of South African Scholars 1981-96", Scientometrics, Cilt: 47, Say1: 1, ss. 75-93.

Kalyane, V. L. ve B. K. Sen (1995), "A Bibliometric Study of the Journal of Oilseeds Research", Annals of Library Science and Documentation, Cilt: 42, Sayl: 4, ss. 121141.

Kozak, Nazmi (1994), “Anatolia Dergisi'nde Yayımlanan Yazılar Üzerine Bir İnceleme”, Anatolia: Turizm Araştırmaları Dergisi, Cilt: 5, Aralık, ss. 22-33.

Kozak, Nazmi (2000), “Türkiye’ de Akademik Turizm Literatürünün Gelişim Süreci Üzerine Bir İnceleme”, DAÜ: Turizm Araştırmaları Dergisi, Cilt: 1, Sayı: 1, ss. 15-55.

Kozak, Nazmi (2003), “Türkiye’ de Yayınlanan Akademik Dergilerin Niteliklerindeki Zaman İçerisindeki Değişim Nedenleri: Sağlık, Sosyal ve Teknik Bilim Alanlarında Yayınlanan Dergiler Üzerine Bir İnceleme”, Bilgi Dünyası, Cilt: 4, Sayı: 2, ss. 146174.

Lawani, S. M (1981), "Bibliometrics: Its Theoretical Foundations, Methods and Applications", International Journal of Libraries and Information Services, Cilt: 31, Say1: 4, ss. 294-315.

Okuba, Yoshiko (1997), "Bibliometric Indicators and Analysis of Research Systems: Methods and Examples", OECD Science, Technology and Industry Working Papers, 1997/01, OECD Publishing, (http://dx.doi.org/10.1787/208277770603).

Özel, Çağıl Hale -Kozak, Nazmi (2012), "Turizm Pazarlaması Alanının Bibliyometrik Profili (2000-2010) ve Bir Atıf Analizi Çalışması”, Türk Kütüphaneciliği Dergisi, Cilt: 26, Sayl: 4, ss. 715-733.

Phene, Anupama ve Stephen Guisinger (1998), "The Stature of the Journal of International Business Studies", Journal of International Business Studies, Cilt: 29, Say1: 3, ss. 621631. 
Polat, Coşkun - Sağlam, Mukaddes - Tuba Sarı (2013), “Atatürk Üniversitesi İktisadi ve İdari Bilimler Dergisi’ nin Bibliyometrik Analizi”, Atatürk Üniversitesi İktisadi ve İdari Bilimler Dergisi, Cilt: 27, Say1: 2, ss. 273-288.

Samiee, Saeed - Chabowski, Brian R (2012), "Knowledge Structure in International Marketing: A Multi-Method Bibliometric Analysis", Journal of the Academy of Marketing Science, Cilt: 40, Say1: 2, ss. 364-386.

Şakar, Gül Denktaş - Cerit, Ayşe Güldem(2013), "Uluslararası Alan İndekslerinde Türkiye Pazarlama Yazını: Bibliyometrik Analizler ve Nitel Bir Araştırma", Atatürk Üniversitesi İktisadi ve İdari Bilimler Dergisi, Cilt: 27, Say1: 4, ss. 37-62.

Vassinen, Antti (2006), "The Concept of Strategic Marketing in Marketing Discourse- A Bibliometric Study", Master's Thesis, Department of Industrial Engineering and Management, Helsinki University of Technology, Institute of Strategy and International Business, Helsinki.

Wung, Chih-Chien - Hu, Wen-Chien (2011), "Bibliometric Analysis of Advertising Endorser Research in Marketing", International Proceedings of Economics Development \& Research, Cilt: 3, ss. 102-106.

Yalçın, Haydar (2010), "Milli Folklor Dergisinin Bibliyometrik Profili", Milli Folklor Dergisi, Cilt: 22, Sayı: 85, ss. 205-211. 
